Revista Brasil. Bot., V.30, n.4, p.713-719, out.-dez. 2007

\title{
Variation between three Eremanthus (Asteraceae) species in their ability to form a seed bank ${ }^{1}$
}

\author{
SIMONE BATALHA VELTEN ${ }^{2}$ and QUEILA SOUZA GARCIA 2,3
}

(received: August 30, 2004; accepted: November 24, 2006)

\begin{abstract}
Variation between three Eremanthus (Asteraceae) species in their ability to form a seed bank) - Knowledge on seed bank function is fundamental for understanding the species regeneration patterns. This investigation was carried out to compare the ability of Eremanthus elaeagnus (Mart. ex DC.) Schultz-Bip, E. glomerulatus Less., and E. incanus (Less.) Less. to form a soil seed bank. Seeds (aquenes) of each of these three species were collected, stored in the laboratory and subsequently buried in the same area where they were collected, inside nylon bags. The bags were collected monthly or bimonthly for germination tests under continuous light and also in darkness at $20^{\circ} \mathrm{C}$ (E. elaeagnus e E. glomerulatus) and at $25^{\circ} \mathrm{C}(E$. incanus). After 12 months, a further series of tests compared the germination of achenes that had been buried in soil and compared with those stored in the laboratory at $15,20,25,30,35$, and $40{ }^{\circ} \mathrm{C}$. After three months of burial, the seeds of E. elaeagnus and $E$. glomerulatus failed to germinate, whereas the seeds of $E$. incanus, even after burial for 18 months, retained germination percentage of between $1 \%$ and $30 \%$. After one year stored in laboratory, the seeds of $E$. glomerulatus were no longer viable and seeds of E. elaeagnus e E. incanus had a germination percentage below that of newly collected seeds. The results showed that E. elaeagnus and E. glomerulatus do not form seed banks while E. incanus may form a small and persistent soil seed bank.
\end{abstract}

Keywords - Asteraceae, buried seeds, Eremanthus, germination, seed bank

RESUMO - (Variação do potencial para formação de banco de sementes de três espécies de Eremanthus (Asteraceae)) - O conhecimento do funcionamento do banco de sementes é importante para se entender os modelos de regeneração das espécies. O objetivo deste trabalho foi comparar a habilidade de Eremanthus elaeagnus (Mart. ex DC.) Schultz-Bip, E. glomerulatus Less. e E. incanus (Less.) Less. para a formação de banco de sementes no solo. Após a coleta os aquênios foram armazenados em laboratório e enterrados na mesma área onde foram coletados, dentro de sacos de nylon. Os sacos foram coletados mensal ou bimestralmente para a realização dos testes de germinação, sob luz e escuro contínuos, a $20^{\circ} \mathrm{C}$ (E. elaeagnus e $E$. glomerulatus) e $25^{\circ} \mathrm{C}$ (E. incanus). Após 12 meses foram realizados testes de germinação nas temperaturas de 15, 20, 25, 30, 35 e $40{ }^{\circ} \mathrm{C}$, com aquênios armazenados no solo e em laboratório. A partir do terceiro mês de armazenamento no solo, não ocorreu germinação de sementes de E. elaeagnus e E. glomerulatus, enquanto as sementes de E. incanus, armazenadas 18 meses, apresentaram percentuais de germinação entre $1 \%$ e $30 \%$. Após um ano de armazenamento em laboratório, sementes de E. glomerulatus não se mantiveram viáveis e sementes de E. elaeagnus e E. incanus apresentaram percentuais de germinação, em geral, inferiores aos obtidos para as sementes recém colhidas. Os resultados mostram que E. elaeagnus e E. glomerulatus não formam banco de sementes e E. incanus pode formar um pequeno banco de sementes persistente no solo.

Palavras-chave - Asteraceae, banco de sementes, Eremanthus, germinação

\section{Introduction}

The term seed bank has been adopted to denote the reserves of viable seeds present in the soil and on its surface (Roberts 1981). Knowing how these seed reserves function is important to understand patterns of regeneration throughout the plant kingdom (Fenner 1995).

The seed bank can be classified as transient, shortterm persistent and long-term persistent (sensu Thompson 1993). Plants with transient seed banks rely upon the

\footnotetext{
1. Part of MSc. Thesis of first author.

2. Universidade Federal de Minas Gerais, Instituto de Ciências Biológicas, Departamento de Botânica, Laboratório de Fisiologia Vegetal, Caixa Postal 486, 30161-970 Belo Horizonte, MG, Brasil. 3. Corresponding author: queila@netuno.lcc.ufmg.br
}

occurrence of dependable regeneration opportunities, such as the seasonal creation of predictable gaps (Thompson \& Grime 1979). In contrast, persistent seed banks are typically characteristic of plant communities that are subject to frequent but unpredictable disturbance, such as that caused by cultivation, fire, or fluctuations in water level, and where opportunities for recolonization occur at random (Fenner 1995, Thompson 1992).

The economic importance of weed seed banks has stimulated considerable research into weed seed survival and emergence (Thompson 1992). The data on weed seed banks include many members of Asteraceae family (Baskin et al. 1995, Carmona \& Villas-Bôas 2001, Corkidi et al. 1991, Rothrock et al. 1993, Severino \& Christoffoleti 2001). Seed bank data for rare species, and non-agricultural habitats such as wetlands, rocky habitats and native 
woodlands, are scarce or even entirely absent (Thompson et al. 1998).

The genus Eremanthus comprises 18 species of trees and shrubs distributed in the arid Central Plateau of Brazil (MacLeish 1987). The members of this genus, locally called "candeia", are subject to intense exploratory pressure, as its stems are often used for fence posts (MacLeish 1987). These plants are also utilized for essential oil production, due to the presence of sesquiterpene lactones that have cytotoxic, anti-tumourgenic, anti-bacterial and anti-fungal properties (Bohlmann et al. 1980, Picman 1986).

Eremanthus glomerulatus and E. incanus are distributed throughout Minas Gerais and adjacent regions in "cerrado" (neotropical savanna) and "campo rupestre" (rocky mountain grassland) habitats (MacLeish 1987), while E. elaeagnus is restricted to "Serra do Espinhaço" and "Serra da Canastra", Minas Gerais State, in "campo rupestre" (MacLeish 1987, Nakajima \& Semir 2001). These species have been listed as presumed threatened species of the flora of Minas Gerais. Even although there is not sufficient information to justify classifying them as threatened, there are nevertheless some indications that might eventually endorse this belief (Mendonça \& Lins 2000).

In an attempt to assist proper strategies and management plants for the conservation this study posses the question: can Eremanthus elaeagnus, E. glomerulatus and E. incanus form soil seed banks?

\section{Materials and methods}

Achenes of E. glomerulatus Less., E. incanus (Less.) Less. and E. elaeagnus (Mart. ex DC.) Schultz-Bip were collected in "Serra do Cipó" (between 19 ${ }^{\circ} 12^{\prime}-19^{\circ} 34^{\prime}$ 'S and $43^{\circ} 27^{\prime}-43^{\circ} 38^{\prime}$ W), Minas Gerais State, on June to August 2001, October 2001 and August 2002 respectively. The climate of "Serra do Cipó" is tropical-montane with annual mean temperatures varying between 17 and $18.5^{\circ} \mathrm{C}$, and annual mean precipitation varying between 1.450 and 1.850 $\mathrm{mm}$ (Antunes 1986). Precipitation mainly falls between December and March (Antunes 1986). Throughout this paper, achenes are referred to as seeds as they are functionally analogous to true seeds (Fenner 1983).

Seeds without signs of predation or wilt were selected for testing. Batches of 300 and 1500 seeds were placed in fine-mesh nylon bags and then buried at about $5 \mathrm{~cm}$ deep in the same area as where they were collected. Until one year of burial, one bag of seeds of each species was exhumed monthly and germination tests were carried out under continuous light and darkness at temperatures of $20{ }^{\circ} \mathrm{C}$ (E. elaeagnus and E. glomerulatus) and $25^{\circ} \mathrm{C}$ (E. incanus).

After one year of burial, it was observed that E. incanus was unique in that it continued to show a capacity for germination. Consequently, germination tests were carried out at temperatures of $15,20,25,30,35$ and $40{ }^{\circ} \mathrm{C}$, with seeds of this species only. After 12 months, the germination tests were done bimonthly, at a temperature of $25^{\circ} \mathrm{C}$, up until 18 months of burial. For the germination tests 4 replicates of 25 seeds were used for each treatment. Emergence of the radicle was the criterion for germination.

In addition, one portion of seeds was stored in paper bags, under no controlled conditions in the laboratory. After one year of storage in these conditions, the germination tests were carried out under continuous light and darkness at temperatures of $15,20,25,30,35$ and $40{ }^{\circ} \mathrm{C}$. The seeds of E. incanus, stored in laboratory, were also submitted to the germination tests at alternating temperatures of 15/25, 15/ $30,15 / 35,20 / 30,20 / 35$ and $25 / 35^{\circ} \mathrm{C}$, with a photoperiod of 12 hours, with the light period coinciding with the higher temperature of each pair.

The viability of the seeds stored in the laboratory was also checked by the tetrazolium test (Delouche et al. 1962). For this test four replicates of 30 seeds were used and soaked in tetrazolium solution $(1 \%)$, at $25^{\circ} \mathrm{C}$, darkness for 24 hours.

The germination rate was estimated by calculating the mean time for germination (Labouriau 1983). As the data obtained had standard deviations with uncertain variation that could not be normalized, the Kruskal-Wallis nonparametric test was carried out. From this mean sequences were compared with a $\mathrm{T}$ test, at $5 \%$ of significance (Sampaio 2002).

\section{Results}

After the first and the second months of burial, seeds of E. elaeagnus showed reduced germination percentages (less than 4\%) both in the light and in the dark. After the third month no further germination occurred. Seeds that did not germinate either had no embryos or were atrophied. When the bag was opened 16 seedlings and some achenes without seeds were found after the first month of burial.

After twelve months of storage under laboratory conditions, seeds of E. elaeagnus could germinate at temperatures between 15 and $30^{\circ} \mathrm{C}$ (figure 1). No significant differences between the percentages obtained in the light and in the darkness were found. The higher germination rates were obtained at 20 and $25^{\circ} \mathrm{C}$, also without significant differences between light and dark. Germination began, in the light and in the darkness, at the temperature of 25 ${ }^{\circ} \mathrm{C}$, five days after initial imbibition.

The viability test showed that, after one year of storage in the laboratory, the percentage of viable $E$. elaeagnus seeds declined from approximately $26 \%$ (newly collected seeds) to $14 \%$. The germination percentages of E. elaeagnus seeds stored in the laboratory were significantly lower than those obtained for newly collected seeds at $30{ }^{\circ} \mathrm{C}$ in the light and 15 and $30{ }^{\circ} \mathrm{C}$ in the darkness (figure 1). 

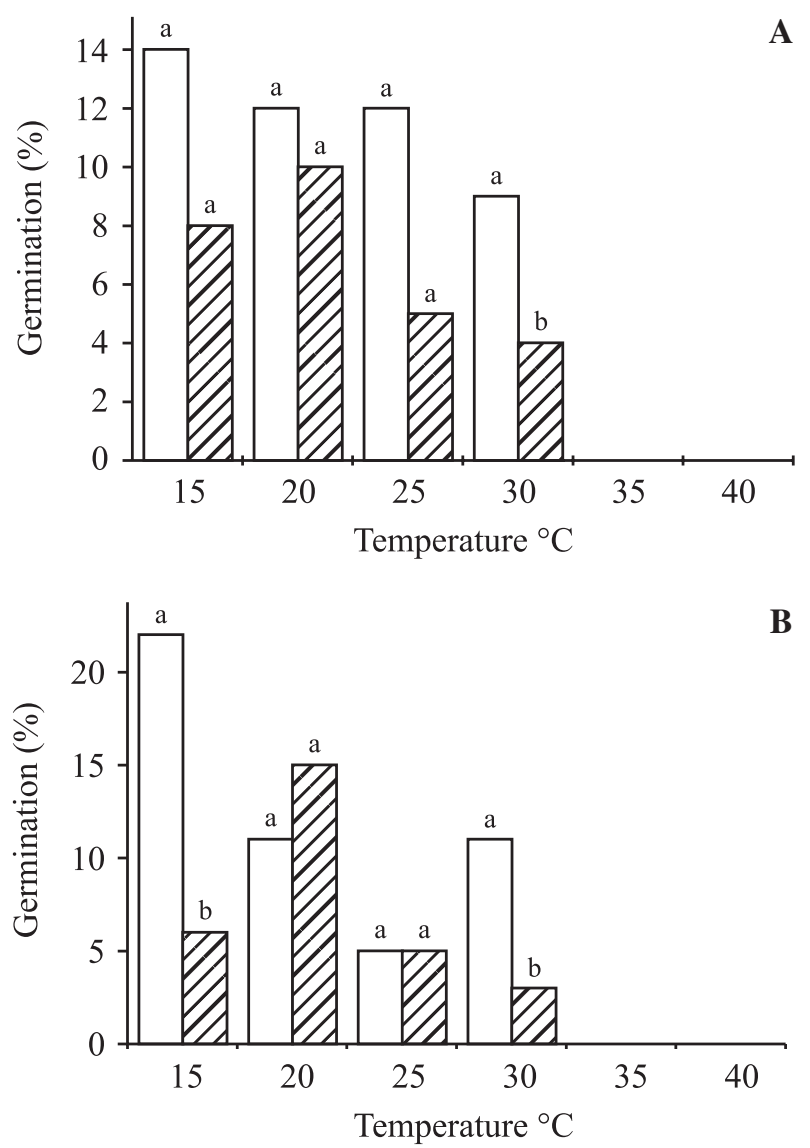

Figure 1. Germination percentage of E. elaeagnus seeds newly collected and storage in laboratory during one year, submitted to light (A) and darkness (B), at temperatures of 15 and $40^{\circ} \mathrm{C}$. Letters compare columns in the same temperature and light condition. ( $\square=$ Newly collected; $\square=$ storage in laboratory).

After the first and the second months of burial, $E$. glomerulatus seeds showed reduced percentages of germination in the light and in the dark. The germination was less than $9 \%$. After the third month, there was no further germination. The seeds that did not germinate either had no embryos or were atrophied. When the bag was open, 27 seedlings and some achenes without seeds were found after the first month of burial. After one year of storage in the laboratory, the seeds showed a reduced germination percentage $(1 \%)$ at temperatures of 15 and $20^{\circ} \mathrm{C}$ and did not germinate at any other temperatures. The viability test showed that $15 \%$ of seeds possessed embryos, but they were unviable.

After burial for 18 months, the E. incanus seeds showed germination percentages varying from $11 \%$ to $30 \%$ in light and from $1 \%$ to $24 \%$ in darkness (table 1 ). When the bags were opened 30 and 19 seedlings were found after the first and the second months of storage respectively. Moreover, a large number of achenes without seeds was also found. In the following months, seedlings were not found, while a large number of achenes without seeds were present. In general, the germination percentages were higher in the light than in the dark, but the differences were not always significant (table 1, figure 2). After the third month, germination percentage in the darkness reduced, except on the ninth month of storage, when the difference were not significant as in the other months (table 1).

After the first two or three months of burial, there was an increase in the germination rate obtained in relation to the newly collected seeds. On the following months, there was a decrease, except after 10 and 14 months, in the light and also in the darkness (figure 2).

After 12 months of burial germination percentages were significantly higher in the light than in the darkness, except at $35{ }^{\circ} \mathrm{C}$ (figure 3 ). The higher germination rate was obtained in the darkness at $25^{\circ} \mathrm{C}$ and in the light at $30{ }^{\circ} \mathrm{C}$. The germination started between the second and the tenth day in the light and between the third and the seventeenth day in the darkness.
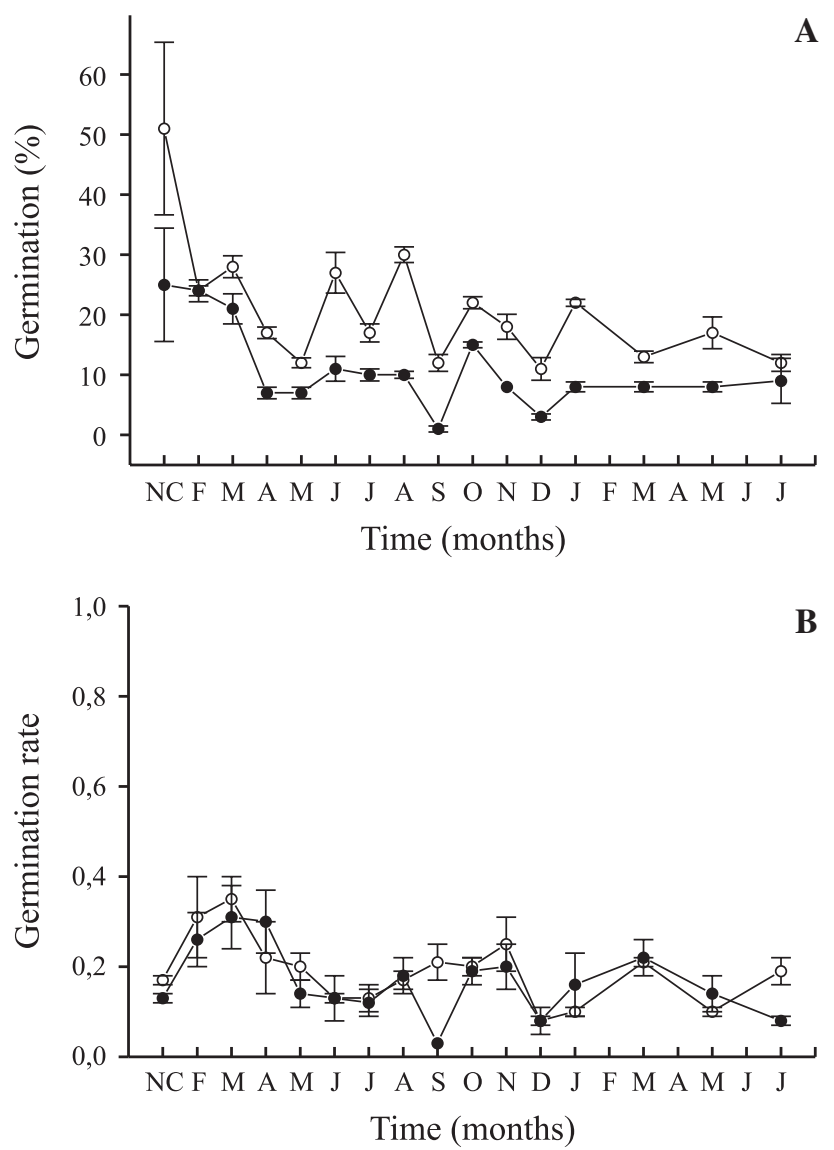

Figure 2. Percentage (A) and germination rate (B) of E. incanus seeds submitted to continuous light or darkness at $25^{\circ} \mathrm{C}$, after 18 months of burial. $\mathrm{NC}=$ newly collected seeds. Bars indicate standard deviation. (-०- Light; $\bullet-$ Darkness). 
Table 1.Germination percentage (G), germination rate (GR) and germination start (GS) of Eremanthus incanus seeds newly collected and buried. Tests were done in continuos light and darkness, at $25{ }^{\circ} \mathrm{C}$. Values followed by same letters are not different. Minuscule letters compare columns and capital letters compare lines.

\begin{tabular}{|c|c|c|c|c|c|c|}
\hline \multirow{2}{*}{$\begin{array}{l}\text { Burial time } \\
\text { (months) }\end{array}$} & \multicolumn{3}{|c|}{ Light } & \multicolumn{3}{|c|}{ Darkness } \\
\hline & $\mathrm{G}(\%)$ & GR & GS (days) & G (\%) & GR & GS (days) \\
\hline 0 & $51 \mathrm{aA}$ & $0,17 \mathrm{deA}$ & 4 & $25 \mathrm{aA}$ & $0,13 \mathrm{fgA}$ & 6 \\
\hline 1 & $24 \mathrm{abcA}$ & $0,31 \mathrm{abA}$ & 2 & $24 \mathrm{aA}$ & $0,26 \mathrm{abA}$ & 2 \\
\hline 2 & $28 \mathrm{abA}$ & $0,35 \mathrm{aA}$ & 2 & $21 \mathrm{aA}$ & $0,31 \mathrm{aA}$ & 2 \\
\hline 3 & 17 bcdeA & $0,22 \mathrm{cdB}$ & 3 & 7 cdeB & 0,3 aA & 2 \\
\hline 4 & $12 \mathrm{eA}$ & $0,20 \mathrm{cdA}$ & 3 & 7 cdeA & 0,14 efB & 5 \\
\hline 5 & 27 abcdA & 0,13 efA & 3 & $11 \mathrm{bcB}$ & 0,13 fgA & 6 \\
\hline 6 & $17 \mathrm{cde} A$ & 0,13 efA & 3 & $10 \mathrm{bcB}$ & 0,12 fghA & 3 \\
\hline 7 & $30 \mathrm{aA}$ & $0,17 \mathrm{dA}$ & 2 & $10 \mathrm{bcB}$ & 0,18 cdeA & 2 \\
\hline 8 & $12 \mathrm{eA}$ & $0,21 \mathrm{cdA}$ & 3 & $1 \mathrm{eB}$ & $0,03 \mathrm{hB}$ & 8 \\
\hline 9 & 22 abcdA & $0,20 \mathrm{cdA}$ & 3 & $15 \mathrm{abA}$ & $0,19 \mathrm{cdA}$ & 3 \\
\hline 10 & 18 bcdeA & $0,25 \mathrm{abcA}$ & 4 & 8 cdeB & $0,20 \mathrm{bcdA}$ & 4 \\
\hline 11 & $11 \mathrm{eA}$ & $0,08 \mathrm{fA}$ & 5 & $3 \mathrm{deB}$ & $0,08 \mathrm{ghA}$ & 8 \\
\hline 12 & $22 \operatorname{abcdA}$ & $0,10 \mathrm{fB}$ & 3 & $8 \mathrm{cdeB}$ & $0,16 \operatorname{def} A$ & 3 \\
\hline 14 & $13 \mathrm{eA}$ & $0,21 \mathrm{bcA}$ & 3 & $8 \mathrm{cde} A$ & $0,22 \mathrm{abcA}$ & 3 \\
\hline 16 & $17 \mathrm{deA}$ & $0,10 \mathrm{fB}$ & 3 & $8 \mathrm{cdeB}$ & 0,14 efA & 5 \\
\hline 18 & $12 \mathrm{eA}$ & $0,19 \mathrm{cdA}$ & 3 & 9 bcdA & $0,08 \mathrm{ghB}$ & 5 \\
\hline
\end{tabular}

After one year of storage in the laboratory the germination in the dark was significantly higher than in the light at $35{ }^{\circ} \mathrm{C}$ (figure 3). Moreover, there were no significant differences between light and the dark germination percentages obtained at other temperatures. The higher germination rates were obtained at temperatures between 20 and $30{ }^{\circ} \mathrm{C}$ in the light and in the dark.

In the experiments with alternating temperatures, seeds of $E$. incanus stored in the laboratory showed higher germination percentage in the $20-35^{\circ} \mathrm{C}$ treatment, without significant differences in relation to $25-35^{\circ} \mathrm{C}$ and $15-25^{\circ} \mathrm{C}$. The higher germination rates were obtained at $20-30{ }^{\circ} \mathrm{C}$ and at $25-35{ }^{\circ} \mathrm{C}$. The germination started between the third (20-30 and $\left.25-35^{\circ} \mathrm{C}\right)$ and the ninth day $\left(15-35^{\circ} \mathrm{C}\right)$.

The viability test showed that after one year of storage in the laboratory the percentage of viable $E$. incanus seeds declined from approximately $51 \%$ (newly collected seeds) to $32.5 \%$. In general, the storage of $E$. incanus seeds reduced the germination percentages in comparison with the newly collected seeds (figure 3 ). However, at the temperature of $35^{\circ} \mathrm{C}$ (in the darkness), the germination percentage of the stored seeds in the laboratory was significantly higher than the germination percentages of newly collected seeds and those seeds stored in the soil (figure 3). The seeds stored in the laboratory showed germination percentages in the darkness higher than the seeds buried, except at $15{ }^{\circ} \mathrm{C}$.
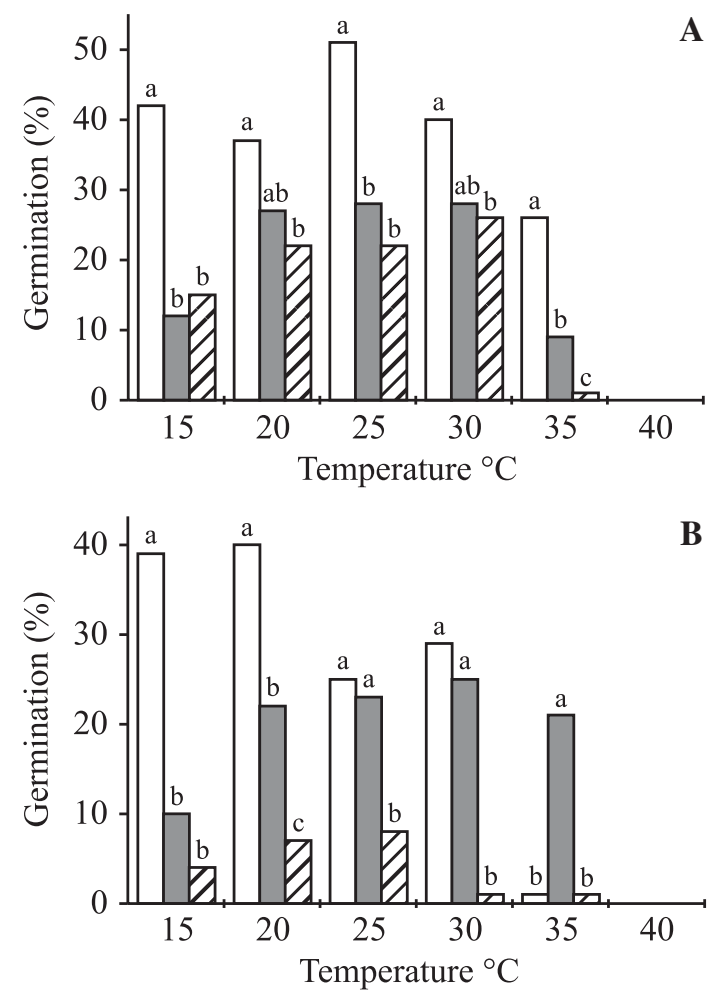

Figure 3. Germination percentage of $E$. incanus seeds newly collected, stored in laboratory and buried, during one year, submitted to light (A) and darkness (B), at temperatures of 15 to $40^{\circ} \mathrm{C}$. Letters compare columns in the same temperature and light condition. ( $\square=$ newly collected; $\square=$ storage in laboratory; $\square=$ buried). 
In the light, these differences were not significant, except at $35^{\circ} \mathrm{C}$ (figure 3 ).

\section{Discussion}

It has been frequently observed that seeds of persistent banks tend to be small and compact, while transient seeds are often larger and either flattened or attenuated (Thompson 1993). The possible selective advantages of small seed size are the facility with which they can be buried by percolating into cracks in the soil and the reduction in the probability of predation (Fenner 1995). However, according to Leishman et al. (2001), this pattern is not universal to all floras and vegetation types. Leishman \& Westoby (1998) found that, for Australian species, the persistent seeds were not smaller or more compact than transient seeds.

Although Asteraceae seeds, in general, are not compactly shaped, some species of this family have the ability to form a persistent seed bank (Baskin et al. 1995, Walck et al. 1998) and many of them are found in the forest seed banks (Araújo et al. 2001, Baider et al. 2001) or in cultivated soils (Severino \& Chrisoffoleti 2001). According to Thompson et al. (1998), the persistence of seeds in the soil depends not only on seed size or shape, but also on other traits, including likelihood of burial, germination physiology and also chemical and physical defenses against predators and pathogens.

According to Thompson \& Grime (1983), the species that present some degree of inhibition of germination by darkness are commonly encountered in the buried seed flora while the majority of those that lack dark germination inhibition are not encountered. Although seeds buried in the soil or stored at room temperature in the laboratory may change their response to light (Vásquez-Yanes \& Orosco-Segovia 1996), seeds of E. elaeagnus, E. glomerulatus and $E$. incanus retained their requirements for light after burial. The seeds of E. elaeagnus and $E$. glomerulatus are aphotoblastic (Velten \& Garcia 2005) and germinate after the first rains even when buried in the soil. Thus, they do not remain in the soil seed bank. On the other hand, seeds of E. incanus that present a degree of inhibition of germination by darkness (Velten \& Garcia 2005) have the ability to form a soil seed bank.

In the soil, suitable conditions for germination, senescence and the presence of predators and pathogens lead to seed bank losses (Simpson et al. 1989). In the case of E. elaeagnus and E. glomerulatus, germination seems to be the main cause of seed loss after burial. After the first and second months of storage, when the bags were opened, the germination of the majority of viable seeds was detected. Many seeds of E. incanus also germinated inside the bags when buried, but the majority of them remained dormant. Since the seeds were buried inside bags, the effect of seed predators could not be evaluated.

Species regeneration strategies do not necessarily involve seed bank formation (Fenner 1995). Vegetative expansion and the capacity to develop a bank of persistent seedlings are alternative means of regeneration (Grime 1989). Eremanthus elaeagnus may reproduce asexually by vegetative expansion, so it probably uses this kind of strategy for regeneration. Analogous results were obtained for Vernonia herbacea, an Asteraceae of the "cerrado", which shows vegetative expansion and which seeds lost their viability after three months of storage in the soil (Sassaki et al. 1999).

In various habitats subjected to low intensities of disturbance the vegetative expansion appears to enjoy a selective advantage (Grime 1989, Fenner 1995). According to Thompson (1992), small-scale disturbances do not select persistent buried seeds. Small gaps, as caused by fall of single tree, are mostly filled by vegetative expansion of surrounding vegetation (Thompson 1992). In addition, vegetative reproduction is much more successful than sexual reproduction under the high fire frequency regimes (Hoffmann 1998), typical of "cerrado" and "campo rupestre" habitats.

Although vegetative expansion was not observed in E. glomerulatus, these possibility shoud be more investigated. Among the three species of Eremanthus, E. glomerulatus shows lower germination percentage (Velten \& Garcia 2005) and also do not have ability to form a soil seed bank. However, this species is found commonly in large colonies and may dominate "cerrado" and "campo rupestre" habitats (MacLeish 1987), being probably first colonizer (Rezende 2002).

Eremanthus incanus can form a small and persistent seed bank of type III (sensu Thompson \& Grime 1979). In this type of bank many seeds germinate soon after they are released, however, another proportion of the seeds fails to germinate directly and some of these become incorporated into a persistent seed bank. According to Gutterman (2001), the phenotypic influences, including environmental and maternal effects, during maturation on seed germination ensure that, even under optimal conditions, only a portion of the seed population will germinate in one rain event or in one season. Then, the germination may be distributed over time, increasing the chances for establishment and growth to maturity of some seedlings (Egley 1995). Over 18 months of burial, the germination percentage of $E$. incanus seeds remained relatively constant and dormancy cycles were not observed. 
Although E. elaeagnus seeds had not preserved viability when buried, they remained viable after one year of storage in laboratory. These seeds did not change their response to light and temperature, while $E$. glomerulatus seeds lost the viability either in soil or in laboratory. The storage of E. incanus seeds for 12 months, in laboratory, changed their requirement for light. After storage, the germination percentage obtained in the darkness, at $35{ }^{\circ} \mathrm{C}$, was significantly higher than that obtained in the light, while the newly collected seeds showed higher percentages in light, at 25 and $35^{\circ} \mathrm{C}$. In general, the storage in laboratory led to the reduction in the germination percentage of one out of the three Eremanthus species studied.

In spite of the fact that Eremanthus elaeagnus, $E$. glomerulatus and E. incanus are congeneric and occur in similar habitats in the "Serra do Cipó", they show different regeneration strategies. Eremanthus elaeagnus and E. glomerulatus do not form a seed bank, while $E$. incanus has the ability to form a small and persistent soil seed bank. Thus, it can be concluded that E. incanus presents a higher potential for regeneration in habitats subjected to frequent but unpredictable disturbance, while E. elaeagnus and E. glomerulatus may show advantages in habitats subjects to low intensities of disturbance.

Acknowledgements - Our special thanks to Dr. José Pires de Lemos Filho and Prof. R.M.M. Crawford for their critical revisions and suggestions; to Dr. Harold Robinson for species identification and to Dr. Ivan Sampaio for his help on statistical analysis.

\section{References}

ANTUNES, F. Z. 1986. Caracterização climática do estado de Minas Gerais. Informativo Agropecuário 12:9-13.

ARAÚJO, M.M., OLIVEIRA, F.A., VIEIRA, I.C.G., BARROS, P.L.C. \& LIMA, C.A.T. 2001. Densidade e composição florística do banco de sementes do solo de florestas sucessionais na região do Baixo Rio Guamá, Amazônia Oriental. Scientia Forestalis 59:115-130.

BAIDER, C., TABARELLI, M. \& MANTOVANI, W. 2001. The soil seed bank during Atlantic Forest regeneration in southeast Brazil. Revista Brasileira de Biologia 61: 35-44.

BASKIN, C.C., BASKIN, J.M. \& CHESTER, E.W. 1995. Role of temperature in the germination ecology of the summer annual Bidens polylepis Blake (Asteraceae). Bulletin of the Torrey Botanical Club 122:275-281.

BOHLMANN, F., ZDERO, C., KING, R.M. \& ROBINSON, H. 1980. Sesquiterpene lactones from Eremanthus species. Phytochemistry 19:2663-2668.
CARMONA, R., VILLAS-BÔAS, H.D.C. 2001. Dinâmica de sementes de Bidens pilosa no solo. Pesquisa Agropecuária Brasileira 36:457-463.

CORKIDI, L., RINCON, E. \& VAZQUEZ-YANES. 1991. Effects of light and temperature on germination of heteromorphic achenes of Bidens odorata (Asteraceae). Canadian Journal of Botany 69:574-579.

DELOUCHE, J.C., SILL, T.W., RASPET, M. \& LIENHARD, M. 1962. The tetrazolium test for seed viability. Missouri Agriculture Experimental Station Technical Bulletin 51:1-63.

EGLEY, G.H. 1995. Seed germination in soil: dormancy cycles. In Seed development and germination (J. Kigel \& G. Galili, eds.). Academic Press, New York, p.529-543.

FENNER, M. 1983. Relationships between seed weight, ash content and seedling growth in twenty-four species of compositae. New Phytologist 95:697-706.

FENNER, M. 1995. Ecology of seed banks. In Seed development and germination (J. Kigel, \& G. Galili eds.). Academic Press, New York, p.507-528.

GRIME, J.P. 1989. Seed banks in ecological perspective. In Ecology of soil seed banks (M.A. Leck, V.T. Parker \& R.L. Simpson, eds.). Academic Press, London, p.xv-xxii.

GUTTERMAN, Y. 2001. Matternal effects on seeds during development. In Seed: the ecology of regeneration in plant communities (M. Fenner, ed.). $2^{\text {nd }}$ ed., CAB International, Wallingford, p.59-84.

HOFFMANN, W.A. 1998. Post-burn reproduction of woody plants in a neotropical savanna: the relative importance of sexual and vegetative reproduction. Journal of Applied Ecology 35:422-433.

LABOURIAU, L.G. 1983. A germinação das sementes. Secretaria Geral da Organização dos Estados Americanos, Washington D.C.

LEISHMAN, M.R. \& WESTOBY, M. 1998. Seed size and shape are not related to persistence in soil in Australia in the same way as in Britain. Functional Ecology 12: 480-485.

LEISHMAN, M.R., WRIGHT, A.T. \& WESTOBY, M. 2001. The evolutionary ecology of seed size. In Seed: the ecology of regeneration in plant communities (M. Fenner, ed.). $2^{\text {nd }}$ ed., CAB International, Wallingford, p.31-57.

MACLEISH, N.F.F. 1987. Revision of Eremanthus (Compositae: Vernonieae). Annals of the Missouri Botanical Garden 74:265-290.

MENDONÇA, M.P. \& LINS, L.V. 2000. Lista Vermelha das Espécies Ameaçadas de Extinção da Flora de Minas Gerais. Fundação Biodiversitas, Fundação Zoo-Botânica de Belo Horizonte, Belo Horizonte.

NAKAJIMA, J.N. \& SEMIR, J. 2001. Asteraceae do Parque Nacional da Serra da Canastra, Minas Gerais, Brasil. Revista Brasileira de Botânica 24:471-478.

PICMAN, A.K. 1986. Biological activities of sesquiterpene lactones. Biochemical Systematics and Ecology 14:255281. 
REZENDE, A.V. 2002. Diversidade, estrutura, dinâmica e prognose do crescimento de um cerrado sensu stricto submetido a diferentes distúrbios por desmatamento. Tese de doutorado, Universidade Federal do Paraná, Curitiba.

ROBERTS, H.A. 1981. Seed banks in soils. Advances in Applied Biology 6:1-55.

ROTHROCK, P.E., SQUIERS, E.R. \& SHEELEY, S. 1993. Heterogeneity and size of a persistent seed bank of Ambrosia artemisiifolia L. and Setaria faberi Herrm. Bulletin of the Torrey Botanical Club 120:417-422.

SAMPAIO, I.B.M. 2002. Estatística aplicada à experimentação animal. $2^{\text {nd }}$ ed. Universidade Federal de Minas Gerais, Belo Horizonte.

SASSAKI, R.M., RONDON, J.N., ZAIDAN, L.B.P. \& FELIPPE, G.M. 1999. Germination of seeds from herbaceous plants artificially stored in cerrado soil. Revista Brasileira de Biologia 59:271-279.

SEVERINO, F.J. \& CHRISTOFFOLETI, P.J. 2001. Banco de sementes de plantas daninhas em solo cultivado com adubos verdes. Bragantia 60:201-204.

SIMPSON, R.L., LECK, M.A. \& PARKER, V.T. 1989. Seed banks: general concepts and methodological issues. In Ecology of soil seed banks (M.A. Leck, V.T. Parker \& R.L. Simpson, eds.). Academic Press, London, p.3-8.

THOMPSON, K. 1992. The functional ecology of seed banks. In Seed: the ecology of regeneration in plant communities (M. Fenner, ed.). $2^{\text {nd }}$ ed., CAB International, Wallingford, p.231-258.
THOMPSON, K. 1993. Persistence in soil. In Methods in comparative plant ecology: a laboratory manual (G.A.F. Hendry \& J.P. Grime, eds.). Chapman \& Hall, London, p.199-202.

THOMPSON, K. \& GRIME, J.P. 1979. Seasonal variations in the seed banks of herbaceous species in ten contrasting habitats. Journal of Ecology 67:893-921.

THOMPSON, K. \& GRIME, J.P. 1983. A comparative study of germination responses to diurnally-fluctuating temperatures. Journal of Applied Ecology 20:141-156.

THOMPSON, K., BAKKER, J.P., BEKKER, R.M. \& HODGSON, J.G. 1998. Ecological correlates of seed persistence in soil in the north-west European flora. Journal of Ecology 86:163-169.

VÁZQUEZ-YANES, C. \& OROZCO-SEGOVIA, A. 1996. Physiological ecology of seed dormancy and longevity. In Tropical Forest Plant Ecophysiology (S.S. Mulkey, R.L. Chazdon \& A.P Smith, eds.). Chapman \& Hall, New York, p.535-558.

VELTEN, S.B. \& GARCIA, Q.S. 2005. Efeitos da luz e da temperatura na germinação de sementes de Eremanthus (Asteraceae), ocorrentes na Serra do Cipó, MG, Brasil. Acta Botanica Brasilica 19:753-761.

WALCK, J.L., BASKIN, J.M. \& BASKIN, C.C. 1998. A comparative study of the seed germination biology of a narrow endemic and two geographically-widespread species of Solidago (Asteraceae). 6. Seed bank. Seed Science Research 8:65-74. 